\author{
Anna Poznańska, Pawet Goryński, Wojciech Seroka, Jakub Stokwiszewski, \\ Pawet Radomski, Bogdan Wojtyniak
}

\title{
NATIONWIDE GENERAL HOSPITAL MORBIDITY STUDY AS A SOURCE OF DATA ABOUT POLISH POPULATION HEALH
}

\author{
OGÓLNOPOLSKIE BADANIE CHOROBOWOŚCI SZPITALNEJ OGÓLNEJ \\ JAKO ŹRÓDŁO DANYCH O PROBLEMACH ZDROWIA LUDNOŚCI POLSKI
}

\author{
National Institute of Public Health - National Institute of Hygiene in Warsaw \\ Department of Population Health Monitoring and Analysis \\ Narodowy Instytut Zdrowia Publicznego - Państwowy Zakład Higieny w Warszawie \\ Zakład Monitorowania i Analiz Stanu Zdrowia Ludności
}

\begin{abstract}
The objective of this article is description of the important source of data on hospitalised morbidity collected in Poland within the frameworks of public statistics, and also underlying the significance of the quality of data collected at the hospital level for the purpose of the practical application of them.

The Nationwide General Hospital Morbidity Study has been conducted by the Department of Population Health Monitoring and Analysis of the NIPH-NIH for more than 40 years within the frameworks of the Programme of Statistical Surveys of Official Statistics. Since the year 2000, it has had a complete character, collecting individual data for all cases of hospitalisation in Poland within the scope compliant with the MZ/Szp- 11 form, among others, sex, age, place of residence of a patient, data on hospital, information about the course of treatment (length of stay in hospital, principal diagnosis and comorbidity, applied medical procedures, the mode of admission and discharge). The collected data are anonymous. In the recent years, annually, more than 8 million of the cases of hospitalisation have been documented.

Almost all obliged hospitals (96\%) participate in the study. Some weak point is the completeness of submitted data, in particular, regarding information about the external causes of injuries and poisonings (in the year 2017, $27 \%$ of the required data were missing). Interestingly, a high level of missing data is generated by a comparatively small number of hospitals. Significant differences are observed in the quality of data depending on the voivodship of hospital location.

The collected data render it possible to, among others, determine the frequency of hospitalisations due to particular causes taking under consideration the localisation of a hospital, and also the sex, age and the place of residence of patients, the analysis of the duration of hospital stay or in-hospital fatality. The aggregated results are reported to international databases (WHO, OECD, Eurostat), and support the administrative authorities of various levels. They are also a basis for numerous published scientific papers. The most important results of routine analyses are presented of the web page of the Study (http://www.statystyka1.medstat.waw.pl/).
\end{abstract}

Key words: Nationwide General Hospital Morbidity Study, hospitalisation, causes of hospitalisation, injuries, quality of data, hospital discharge

\section{STRESZCZENIE}

Celem pracy jest przekazanie wiedzy o zasobach i ograniczeniach danych na temat chorobowości hospitalizowanej w Polsce, dostępnych w ramach statystyki publicznej, a także pokazanie znaczenia jakości danych zbieranych na poziomie szpitali dla ich praktycznego wykorzystania.

Ogólnopolskie Badanie Chorobowości Szpitalnej Ogólnej jest prowadzone w Zakładzie Monitorowania i Analiz Stanu Zdrowia Ludności NIZP-PZH w ramach Programu Badań Statystycznych Statystyki Publicznej. Od 2000 r. ma ono charakter pełny - gromadzi przekazywane przez szpitale jednostkowe dane o wszystkich przypadkach hospitalizacji w zakresie zgodnym z formularzem MZ/Szp-11, obejmujące m. in. płeć wiek, miejsce zamiesz- 
kania pacjenta, dane placówki, informacje o przebiegu leczenia (okres pobytu w szpitalu, choroba zasadnicza i współwystępujące, zastosowane procedury medyczne, tryb przyjęcia i wypisu). Dane te mają charakter anonimowy. W ostatnich latach rocznie dokumentowanych jest ponad $8 \mathrm{mln}$ przypadków hospitalizacji, od 2000r. zgromadzono ponad 120 mln rekordów.

W Badaniu bierze udział 96\% zobowiązanych do tego placówek. Jego słabą stroną jest kompletność nadsyłanych danych zwłaszcza w zakresie informacji o zewnętrznych przyczynach urazów i zatruć (w 2017 roku 27\% braków). Braki te generuje stosunkowo niewielka liczba szpitali. Obserwuje się znaczne różnice w jakości danych pochodzących z poszczególnych województw.

Zbierane dane umożliwiają m. in. wyznaczenie częstości hospitalizacji z poszczególnych przyczyn z uwzględnieniem lokalizacji szpitala oraz płci, wieku i miejsca zamieszkania pacjentów, analizę długości hospitalizacji czy śmiertelności szpitalnej. Wyniki są wykorzystywane do celów statystycznych, zasilają międzynarodowe bazy danych (WHO, OECD, Eurostat), wspierają władze administracyjne różnego szczebla. Są również podstawą wielu prac naukowych. Najważniejsze wyniki analiz rutynowych przedstawiane są na stronie internetowej Badania (http://www.statystyka1.medstat.waw.pl/).

Stowa kluczowe: Ogólnopolskie Badanie Chorobowości Szpitalnej Ogólnej, hospitalizacja, przyczyny hospitalizacji, urazy, jakość danych

\section{INTRODUCTION}

Information about the causes, and the frequency, of hospitalisations constitute one of major elements in the analysis and assessment of population health. It goes without saying that they fail to provide the complete picture of the situation; hospitalisation is determined by the severity of the course of disease, the possibility of making a diagnosis and providing an appropriate treatment in outpatient setting, the selection of admissions connected with the availability of hospital beds, or, alternatively, socio-economic factors. On the other hand, the precision and accuracy of hospital diagnoses exceeds the diagnostic accuracy in other systems of health information. For that very reason, these data on the subject are acquired for the purposes of statistics in numerous countries of the world. In connection with other routinely collected information, these data constitute a significant element of planning actions within the scope of health policy. They refer both to the fulfilled health needs of population (the frequency of hospitalisations due to particular causes), and the quality of treatment (applied medical procedures, length of hospital stay, in-hospital fatality, further hospitalisations due to the same cause, life expectancy after an episode of hospitalisation).

It is the objectives of this paper to provide researchers from various domains with information concerning data on hospitalised morbidity collected in Poland within the frameworks of public statistics, and also to demonstrate to the employees of hospitals involved in the reporting processes that their work, not always appreciated, constitutes a source of important epidemiological data the quality of which determines the possibilities of using them.

\section{WSTĘP}

Informacje o przyczynach i częstości hospitalizacji stanowią jeden z ważniejszych elementów w analizie i ocenie stanu zdrowia ludności. Nie dają one oczywiście pełnego obrazu sytuacji - hospitalizacja jest uwarunkowana ciężkością przebiegu choroby, możliwością ustalenia rozpoznania i zapewnienia właściwego leczenia poza szpitalem, selekcją przyjęć związaną z dostępnością łóżek szpitalnych, czy też czynnikami społeczno-ekonomicznymi. $Z$ drugiej jednak strony dokładność i trafność rozpoznań szpitalnych przewyższa poprawność diagnostyczną w innych systemach oceny stanu zdrowia ludności. Dlatego dane na ten temat są pozyskiwane dla celów statystycznych w wielu krajach świata. W połączeniu z innymi rutynowo zbieranymi informacjami stanowią one istotny element planowania działań z zakresu polityki zdrowotnej. Mówią zarówno o zaspokojonych potrzebach zdrowotnych ludności (częstość hospitalizacji z poszczególnych przyczyn), jak i o jakości leczenia (zastosowane procedury medyczne, długość pobytu w szpitalu, śmiertelność szpitalna, kolejne hospitalizacje z tej samej przyczyny, długość życia po zdarzeniu wymagającym hospitalizacji).

Niniejszy artykuł stawia sobie dwa cele - przekazanie badaczom z różnych dziedzin informacji o zasobach i ograniczeniach danych na temat chorobowości hospitalizowanej, zbieranych w Polsce w ramach statystyki publicznej oraz pokazanie pracownikom szpitali informacji związanych z procesem sprawozdawczości, że ich nie zawsze doceniana praca stanowi źródło ważnych danych epidemiologicznych, których jakość determinuje możliwości ich wykorzystania. 


\section{OUTLINE OF THE NATIONWIDE GENERAL HOSPITAL MORBIDITY STUDY}

In Poland, data on patients discharge from hospitals have been collected, with short intervals, since the mid-1950s. Since $1^{\text {st }}$ January, 1979, the Nationwide General Hospital Morbidity Study (NGHMS) has been conducted upon the basis of the methodology developed by then Department of Medical Statistics in the National Institute of Hygiene (currently, the Department of Population Health Monitoring and Analysis of the NIPH-NIH). Till 1999 the study was based on a random sample of $10 \%$, while since 2000 data on all discharged patients have been analysed.

The study is conducted within the frameworks of the Programme of Statistical Surveys of Official Statistics (PSSOS), an official specification determining the scope of statistical studies conducted in Poland, adopted annually by the Council of Ministers by means of passing an ordinance. Currently, the program for the year 2019 (Journal of Laws of $6^{\text {th }}$ November, 2018, item 2103) is in force. The NGHMS constitutes a part of the study on hospitalisation (symbol 1.29.03(089) in 2018), the conducting body of which is the minister competent in the matters of health. The minister has commissioned this task to the National Institute of Public Health - National Institute of Hygiene in the part relevant to general hospitalisation (where it is performed as the NGHMS), and also to the Institute of Psychiatry and Neurology (within the scope of psychiatric hospitalisations).

The PSSOS sets outs in detail the scope of collected data, and indicates institutions obliged to contribute them. In the case of the NGHMS, these institutions are all entities performing medical activity (since the year 2015, subordinated to the Ministry of the Interior and Administration as well), providing inpatient and round-the-clock medical services, with the exception of those providing psychiatric care (contributing data to the Institute of Psychiatry and Neurology), institutions/ wards, nursing and the health care ones, inpatient hospices, wards of palliative medicine, hospitals and spas. The hospitals managed by Ministry of National Defence and Ministry of Justice are not obliged to participate in the NGHMS, some of them do it voluntarily. For each and every individual that is provided with inpatient medical services, including the one-day services of the dialysis therapy and chemotherapy of neoplasms, a reporting form (MZ/Szp-11) is filled in.

The scope of the collected data includes data on hospital (identification code, National Business Registry Number, territorial code (TERYT) of the localisation, year and number of the General Ledger), patient (sex, date of birth and TERYT of the commune of residence) and stay in a hospital (dates of: referring to hospital, entering into the list of awaiting admission, admission

\section{CHARAKTERYSTYKA OGÓLNOPOLSKIEGO BADANIA CHOROBOWOŚCI SZPITALNEJ OGÓLNEJ}

W Polsce dane o wypisach ze szpitali zbierane są z niewielkimi przerwami od połowy lat pięćdziesiątych. Od 1 stycznia 1979 roku Ogólnopolskie Badanie Chorobowości Szpitalnej Ogólnej (OBChSO) jest prowadzone na podstawie metodyki opracowanej przez ówczesny Zakład Statystyki Medycznej Państwowego Zakładu Higieny (obecnie Zakład Monitorowania i Analiz Stanu Zdrowia Ludności NIZP-PZH). Od 2000 r. ma ono charakter pełny i obejmuje wszystkich pacjentów leczonych w szpitalach (wcześniej było wykonywane na 10\% losowej próbie).

Badanie jest realizowane $w$ ramach Programu Badań Statystycznych Statystyki Publicznej (PBSSP) - oficjalnego wykazu określającego zakres prowadzonych w kraju badań statystycznych, przyjmowanego corocznie przez Radę Ministrów w drodze rozporządzenia. Obecnie obowiązuje Program na rok 2019 (Dz. U. 6 listopada 2018, poz. 2103). OBChSO stanowi część badania Hospitalizacja (symbol 1.29.03(089) w PBSSP 2018), którego organem prowadzącym jest minister właściwy do spraw zdrowia. Zlecił on to zadanie Narodowemu Instytutowi Zdrowia Publicznego - Państwowemu Zakładowi Higieny w części dotyczącej hospitalizacji ogólnej, gdzie jest wykonywane jako OBChSO oraz Instytutowi Psychiatrii i Neurologii w zakresie hospitalizacji psychiatrycznych.

PBSSP szczegółowo precyzuje zakres zbieranych danych i wskazuje instytucje zobowiązane do ich przekazania. W przypadku OBChSO są to wszystkie podmioty wykonujące działalność leczniczą (od 2015 roku również podległe MSWiA), udzielające stacjonarnych i całodobowych świadczeń zdrowotnych z wyjątkiem prowadzących opiekę psychiatryczną (przekazujących dane do Instytutu Psychiatrii i Neurologii), zakładów/ oddziałów pielęgnacyjno-opiekuńczych i opiekuńczo-leczniczych, hospicjów stacjonarnych, oddziałów medycyny paliatywnej, szpitali i sanatoriów uzdrowiskowych. Placówki podlegające Ministerstwu Obrony Narodowej i Ministerstwu Sprawiedliwości nie mają obowiązku udziału w Badaniu, część z nich robi to dobrowolnie. Dla każdej osoby, na rzecz której wykonywane są stacjonarne świadczenia lecznicze, $w$ tym jednodniowe dializoterapii i chemioterapii nowotworów, wypełniany jest formularz sprawozdawczy MZ/Szp-11.

Zakres zbieranych danych obejmuje dane dotyczące placówki (kod identyfikacyjny, REGON, kod terytorialny (TERYT) lokalizacji, rok i numer Księgi Głównej), pacjenta (płeć, datę urodzenia i TERYT gminy zamieszkania) i pobytu w szpitalu (daty: skierowania do szpitala, wpisania na listę oczekujących, przyjęcia i wypisu, numer w Księdze Głównej, nazwy i kody oddziałów, na 
and discharge, number in the General Ledger, names and codes of wards at which the patient was treated, the mode of admission and discharge, payer). In accordance with the Ordinance of the Minister of Health on the scope of indispensable information collected by service recipients, detailed manner of registering information, and also contributing it to the entities obliged to finance services with the use of public means of $20^{\text {th }}$ June, 2008, as further amended (consolidated text in: Journal of Laws of $17^{\text {th }}$ February 2016, item 192, further changes relevant to the subject-matter: Journal of Laws of $11^{\text {th }}$ April, 2016, item 482), the following, among others, modes of admission are listed: emergency mode admission, planned mode admission, transfer from another hospital, together with the following modes of discharge: completing the therapeutic or diagnostic process, referring for treatment in the outpatient setting, to another hospital, to an institution not being hospital, discharge upon request, death of a patient. In the latter case, the immediate, intermediate and underlying causes of death are stated and coded, which makes the MZ/Szp11 card the sole source of data on the chain of events that led to the death.

Stay at every ward is described separately; the dates of admission and discharge, a main disease in accordance with a clinical diagnosis, if needed, together with additional information (diagnosis from the S00-T98 group - Injury, poisoning and certain other consequences of external causes ought always to be accompanied by information about the external cause of it (V01-Y98)), comorbidity significant in the case of this hospitalisation, performed operational and medical procedures. Diseases are defined in accordance with the International Statistical Classification of Diseases and Related Health Problems, 10th Revision (ICD-10), procedures in accordance with the ICD-9 classification (modified on an on-going basis by NHF). Since the year 2014, at the request of the Department of Mother and Child of the Ministry of Health in the case of neonates born in hospital information about a premature delivery has been contributed as well (by means of indicating YES/NO), together with that about the method of feeding at the moment of discharge (solely breast feeding, or with pumped milk/mixed/artificial).

The data are submitted to the NIPH-NIH by electronic means directly by hospitals or with provincial offices acting as intermediaries. The computer system of logical checks renders it impossible to contribute data containing certain mistakes (for instance, diagnoses or procedures impossible in the case of a patient of a given sex or age, the date of discharge earlier than the one of admission) or gaps (for instance, in a principal diagnose or in the TERYT localisation of hospital). In the year 2017, individual data relevant to more than 8.8 million cases of finished hospitalisations were contributed. These których był leczony, tryb przyjęcia i wypisu, płatnik). Zgodnie z Rozporządzeniem Ministra Zdrowia w sprawie zakresu niezbędnych informacji gromadzonych przez świadczeniodawców, szczegółowego sposobu rejestrowania tych informacji oraz ich przekazywania podmiotom zobowiązanym do finansowania świadczeń ze środków publicznych z dnia 20 czerwca 2008 z późniejszymi zmianami (tekst jednolity Dz. U. z 17 lutego 2016, poz. 192, dalsze zmiany dotyczące tematu Dz. U. z 11 kwietnia 2016 poz. 482) tryb przyjęcia wyróżnia $\mathrm{m}$. in. przyjęcia w trybie nagłym, planowym, przeniesienie z innego szpitala, zaś tryb wypisu - zakończenie procesu terapeutycznego lub diagnostycznego, skierowanie do leczenia w lecznictwie ambulatoryjnym, innym szpitalu, placówce nibędącej szpitalem, wypis na własne żądanie, zgon pacjenta. W przypadku zgonu podaje się i koduje jego bezpośrednią, wtórną i wyjściową przyczynę, co czyni z karty MZ/Szp-11 jedyne źródło danych na temat łańcucha przyczyn zgonów.

Pobyt na każdym oddziale opisywany jest oddzielnie - podaje się daty przyjęcia i wypisu, chorobę zasadniczą wg rozpoznania klinicznego, w razie potrzeby $\mathrm{z}$ informacją dodatkową (rozpoznaniu z grupy S00-T98 - Urazy, zatrucia i inne określone skutki działania czynników zewnętrznych zawsze powinna towarzyszyć informacja o jego zewnętrznej przyczynie (V01-Y98)), choroby współwystępujące, istotne w przypadku tej hospitalizacji, wykonane zabiegi operacyjne i procedury medyczne. Choroby określane są zgodnie z X Rewizją Międzynarodowej Statystycznej Klasyfikacji Chorób i Problemów Zdrowotnych (ICD-10), procedury wg Międzynarodowej Klasyfikacji Procedur Medycznych ICD-9 (na bieżąco modyfikowanej przez NFZ). Od 2014 roku na życzenie Departamentu Matki i Dziecka Ministerstwa Zdrowia, w przypadku urodzonych w szpitalu noworodków, przekazuje się również informację o przedwczesnym urodzeniu (w układzie TAK/NIE) i sposobie karmienia w momencie wypisu (wyłącznie piersią lub pokarmem odciąganym/ mieszane/ sztuczne).

Dane nadsyłane są do NIZP-PZH drogą elektroniczną bezpośrednio przez szpitale lub za pośrednictwem Urzędów Wojewódzkich. Komputerowy system sprawdzeń logicznych uniemożliwia przekazanie danych zawierających pewne błędy (np. rozpoznania lub procedury niemożliwe w przypadku pacjenta określonej płci lub wieku, data wypisu wcześniejsza od daty przyjęcia) lub braki (np. rozpoznania zasadniczego lub TERYT-u lokalizacji szpitala). W 2017 roku nadesłano jednostkowe dane dotyczące ponad 8,8 miliona przypadków zakończonych hospitalizacji. Obejmują one wszystkich leczonych, bez względu na status ubezpieczenia i kraj zamieszkania. Dane są anonimowe, nie zawierają personaliów ani innych identyfikatorów pacjentów (PESEL czy numer ubezpieczenia). Od momentu przejścia na system pełny (2000 rok) OBChSO zarejestrowało ponad 120 mln przypadków hospitalizacji. 
data encompass all the treated regardless of the status of their insurance and the country of residence. The data are anonymous, and they do not include personal data or other data which could be used to identify patients (CESPR or insurance number). Since the moment when the complete system was implemented (the year 2000), the NGHMS recorded more than 120 million cases of hospitalisations.

It ought to be emphasised that the NGHMS is the only source of data about the external causes of hospitalised injuries and poisonings in Poland. The NHF, as the payer, collects data about the treatment of the results of an accident but not about the circumstances in which it occurred.

\section{LIMITATIONS OF THE STUDY}

Limitations of the Study partly result from the legal regulations in force related to the protection of personal data. The anonymous character of the collected data renders it impossible to, among others, track the further hospitalisations of an individual (for instance, due to the same cause), or to combine information acquired from various sources (for instance, with the data about deaths collected by the Statistics Poland or those about disability collected by the Social Insurance Institution). It is not possible, for instance, to analyse survival after hospitalisation however, in-hospital fatality can be analysed. The lack of social and demographic data (education, source of income and marital status) restricts the opportunities of the analysis of the determinants of hospitalisation (for instance, in the studies of the social inequalities in health).

Further limitation of the NGHMS results from the completeness and the quality of data. A sharp improvement in the completeness (measured by the percentage of hospitals participating in the study in comparison with the total number of obliged institutions) was achieved in the year 2003 (Fig. 1A). In the recent years, it has remained at the acceptable level of $96 \%$. Information about the completeness of reporting of all hospitals is available at the following Internet address: http://www.statystyka1. medstat.waw.pl/Informacyjna. html.

However, what is found disturbing is the significant, and constantly observed for years, differentiation in the aspect of the completeness of the contributed data between particular voivodships. In the year 2017, all hospitals from the Kujawsko-pomorskie, Lubelskie, Łódzkie, Opolskie, Pomorskie, Podkarpackie, and Śląskie voivodships participated in the NGHMS, whereas, traditionally, the lowest level of representation (below 85\%) was that of the Dolnośląskie and Podlaskie ones (Fig. 2A). As a result of that, the values of the hospitalisation rates for particular provinces calculated upon the basis of collected data vary in reliability, and some of them have to be estimated taking under consideration the proportion of missing data.
Trzeba podkreślić, że OBChSO jest jedynym w Polsce źródłem danych o przyczynach hospitalizowanych urazów i zatruć. NFZ, jako płatnik, zbiera dane o leczeniu skutków wypadków, ale nie o okolicznościach, w jakich do nich doszło.

\section{OGRANICZENIA BADANIA}

Ograniczenia badania częściowo wynikają z obowiązujących rozwiązań prawnych, dotyczących ochrony danych osobowych. Anonimowość zbieranych danych uniemożliwia m. in. śledzenie kolejnych hospitalizacji jednej osoby (np. z tej samej przyczyny) lub łączenie informacji pochodzących z różnych źródeł (np. z danymi o zgonach GUS lub niepełnosprawności ZUS). Nie można też analizować okresów przeżycia po zdarzeniu wymagającym hospitalizacji, a jedynie śmiertelność szpitalną. Brak danych społeczno-demograficznych (wykształcenie, źródło utrzymania, stan cywilny) ogranicza możliwości analizy uwarunkowań hospitalizacji (np. w badaniach społecznych nierówności w zdrowiu).

Kolejne ważne ograniczenia OBChSO stanowią kompletność i jakość danych. Skokową poprawę kompletności (mierzonej odsetkiem szpitali biorących udział w badaniu w stosunku do ogółu do tego zobowiązanych) uzyskano w 2003 roku (Ryc. 1A). W ostatnich latach kształtuje się ona na akceptowalnym poziomie 96\%. Informacje o udziale poszczególnych szpitali są dostępne na stronie: http://www.statystyka1. medstat.waw.p1/Informacyjna.html.

Niepokoi jednak znaczne i utrwalone od lat zróżnicowanie kompletności przekazywanych danych między poszczególnymi województwami. W 2017 roku udział w OBChSO brały wszystkie szpitale $\mathrm{z}$ woj. kujawsko-pomorskiego, lubelskiego, łódzkiego, opolskiego, pomorskiego, podkarpackiego i śląskiego, zaś tradycyjnie najmniej (poniżej 85\%) z dolnośląskiego i podlaskiego (Ryc. 2A). W konsekwencji wyliczane ma podstawie zgromadzonych danych wartości wskaźników hospitalizacji dla poszczególnych województw mają różną wiarygodność, niektóre muszą być szacowane z uwzględnieniem stopnia brakujących danych. Na jeszcze większe trudności napotyka analiza na poziomie powiatów.

Ponadto nadsyłane dane nie zawsze są kompletne, co utrudnia lub wręcz uniemożliwia ich analizę, przekładając się na rzetelność wyciąganych na tej podstawie wniosków.

Słabym punktem Badania są informacje o procedurach zastosowanych podczas leczenia szpitalnego. Mimo że z każdą hospitalizacją łączyć się może wiele procedur, aż $8,2 \%$ rekordów przekazanych w 2017 roku nie zawierało żadnych informacji na ten temat. Warto jednak zaznaczyć, że w ostatnich latach sytuacja $\mathrm{w}$ tej dziedzinie nieco się poprawiła (Ryc. 1B). 

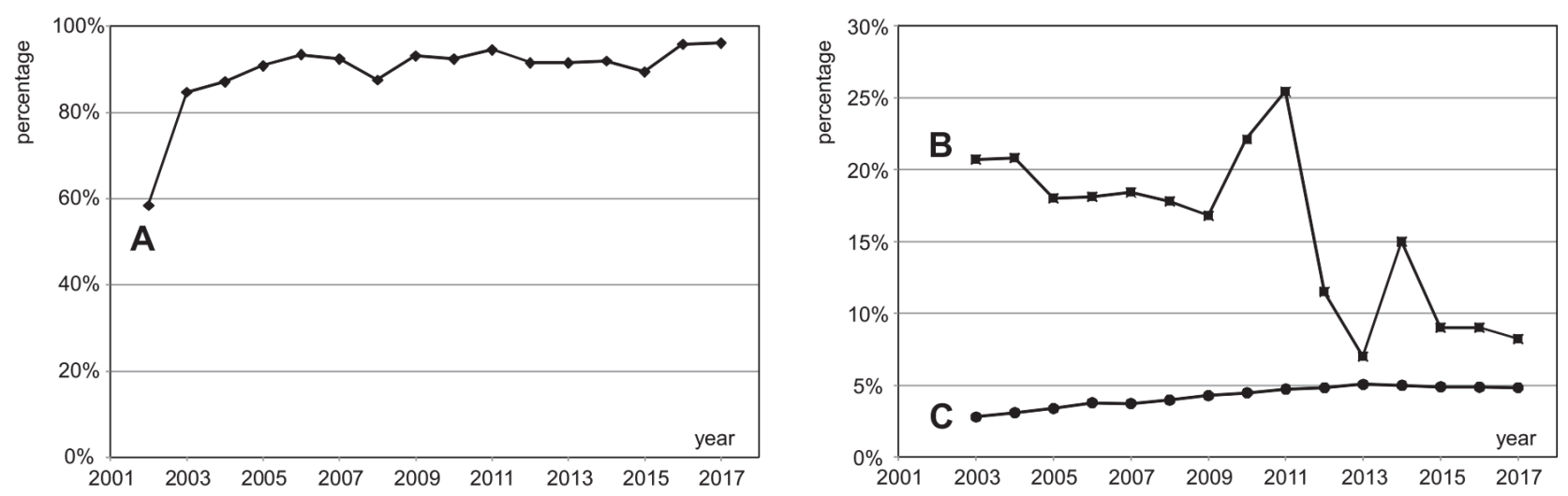

Fig. 1. Selected characteristics of NGHMS: A - percentage of contributing hospitals (2002-2017), B - percentage of records without medical procedures data (2003-2017), C - percentage of hospitalisations due to symptoms, signs and abnormal clinical and laboratory findings, R00-R99 by ICD-10 (2003-2017).

Ryc. 1. Wybrane charakterystyki OBChSO: A - odsetek szpitali przekazujących dane (2002-2017), B - odsetek rekordów bez informacji o procedurach medycznych (2003-2017), C - odsetek hospitalizacji z przyczyn niedokładnie określonych, R00-R99 (2003-2017).

Even more serious problems are encountered in the case of analysis at the level of counties (powiats).

Moreover, not always are the submitted data complete, which renders it difficult, or downrightly impossible, to conduct the analysis of them, and finds its reflection in the reliability of conclusions drawn upon their basis. An imperfection of the Study is information about procedures applied in the course of hospital treatment, and $8.2 \%$ of the records contributed in the year 2017 did not contain any information about them. Moreover, there are noticeable differences between voivodships (Fig. 2B); in the year 2017, the percentage of the missing data was within the scope of $0 \%$ (in Śląskie) to $17.4 \%$ (Świętokrzyskie). However, it is worth indicating that, in the recent years, the situation in this field has been slightly improved (Fig. 1B).
Jednocześnie jakość danych w tej kwestii wykazuje duże zróżnicowanie między województwami (Ryc. 2B), w roku 2017 procent braków mieścił się w zakresie od $0 \%$ (województwo śląskie) do $17,4 \%$ (świętokrzyskie).

Wysoki w skali kraju odsetek braków generuje stosunkowo nieliczna grupa szpitali. W ostatnich latach odsetek rekordów niezawierających danych o procedurach dla $3 / 4$ placówek nie przekraczał $1 \%$, jednak prawie 5\% szpitali nadesłało ponad połowę niekompletnych pod tym względem danych.

Jakość danych w dużym stopniu wynika z rzetelności wypełniania karty statystycznej MZ/Szp-11 w szpitalu. Najlepszym przykładem jest tu podawanie informacji, czy urodzone w szpitalu dziecko było wcześniakiem, w części dotyczącej sposobu karmienia niemowląt.
A

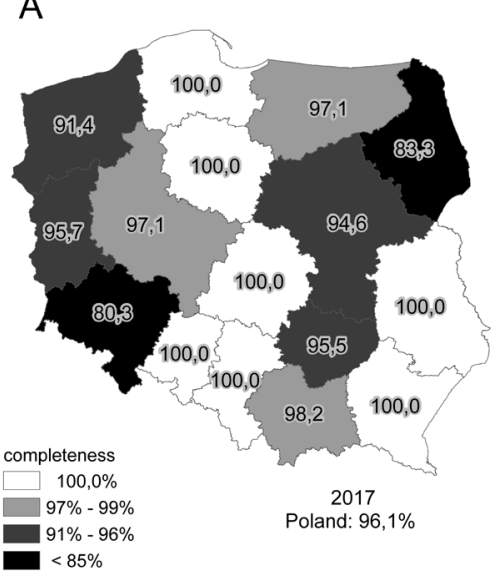

B

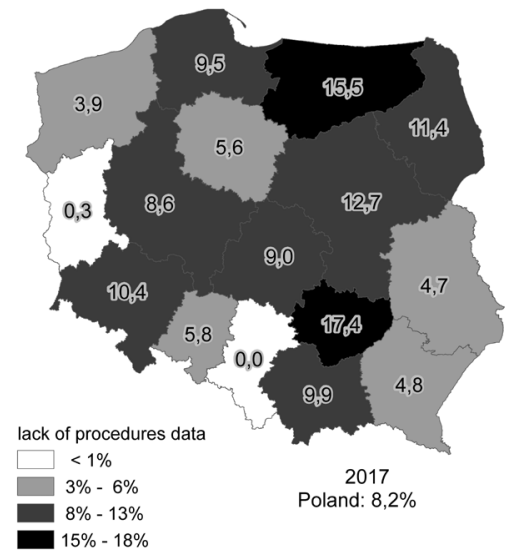

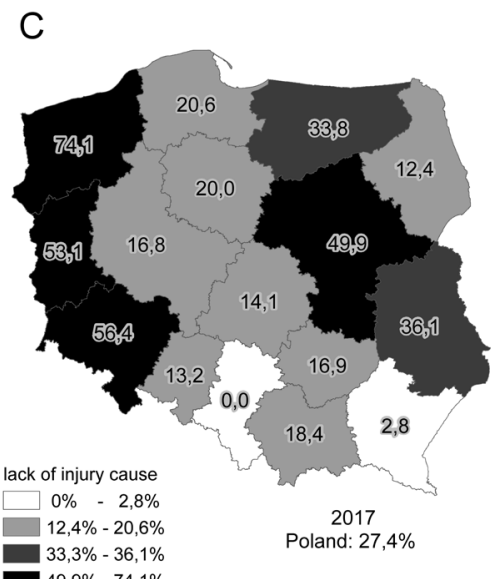

Fig. 2. Selected characteristics of NGHMS by voivodships in 2017: A - percentage of contributing hospitals, B - percent age of records without medical procedures data, $\mathrm{C}$ - percentage of missing data concerning external causes of injuries and poisonings.

Ryc. 2. Wybrane charakterystyki OBChSO według województw w 2017 roku : A - odsetek szpitali przekazujących dane, B - odsetek rekordów bez informacji o procedurach medycznych, C - odsetek braków danych o przyczynach urazów i zatruć. 
A high, in the nationwide scale, percentage of missing data is generated by a comparatively small group of hospitals. In the recent years, the percentage of records not contributing data about procedures for $3 / 4$ institutions did not exceed $1 \%$, however, nearly $5 \%$ hospitals sent more than half of the records incomplete in these terms.

The quality of data results, to a significant degree, from the level of reliability in terms of filling in an MZ/ Szp-11 statistical form in hospital. The best instance in that case is providing information whether a child born in hospital was delivered prematurely, which is relevant to the manner of feeding infants. In spite of the fact that hospital has such knowledge at disposal (the duration of pregnancy is entered into a delivery sheet handed over to parents), $10.4 \%$ of the records received in the year 2017 failed to contain this information. Such a high percentage of missing data was generated by a single voivodship, namely Mazowieckie (58.5\% of the missing data), followed by Lubelskie, in which it amounted to $4.9 \%$, whereas in the majority of the remaining voivodships it did not reach $1 \%$.

Further limitations of the study are constituted by information about the external causes of injuries and poisonings. In the year 2015 , solely in $64.3 \%$ of the these cases was information about their external causes provided, in the year 2016 this percentage equalled $72.4 \%$, whereas in the year $2017-72.6 \%$. The diversity of the quality of these data in terms of the areas of origin is very significant (Fig. 2C) - the causes of injuries are included in $100 \%$ of records submitted from Śląskie voivodship, and 97\% from the Podkarpackie one, whereas in a few voivodships (Zachodniopomorskie, Dolnośląskie, and Lubuskie) this percentage was lower than $50 \%$. Consequently, the quality of data renders it impossible to, among others, assess the impact on health of accidents, to estimate costs of treatment of the casualties, and to identify risk factors and to plan preventive actions.

Hospitalisations due to ill-defined conditions (according to ICD-10 - Symptoms, signs and abnormal clinical and laboratory findings, not elsewhere classified, R00-R99) are an issue combining the problem of medical care and the quality of data. In spite of the fact that both in Poland and elsewhere in the world it is recommended that such diagnoses be restricted as the main cause of hospitalisation $(1,2)$, in our country they constitute nearly $5 \%$ of the total number (in the case of children and adolescents, the percentage is significantly higher, namely, in the year 2017, such was a diagnosis in the case of $8.9 \%$ hospitalised at the age: $5-14$, and $10.3 \%$ at the age: 14-19). Most frequently (in more than 30\%) such diagnoses are observed in the case of abdominal and pelvic pain (R10), followed by pain in the throat and
Mimo że szpital dysponuje taką wiedzą (okres trwania ciąży wpisywany jest do wydawanej rodzicom karty urodzenia), 10,4\% rekordów nadesłanych w 2017 roku nie zawierało tej informacji. Tak wysoki odsetek braków generowało jedno województwo - mazowieckie (58,5\% braków), w następnym w kolejności, lubelskim, wynosił on $4,9 \%$, zaś w większości pozostałych poniżej $1 \%$.

Kolejne ograniczenie badania stanowią informacje o zewnętrznych przyczynach urazów i zatruć. W 2015 roku tylko w $64,3 \%$ przypadków rozpoznanych urazów lub zatruć towarzyszyły informacje o ich zewnętrznej przyczynie, w 2016 - 72,4\%, w 2017 - 72,6\%. Zróżnicowanie przestrzenne jakości tych danych jest bardzo duże (Ryc. 2C) - przyczyny urazów zawiera 100\% rekordów nadsyłanych z województwa śląskiego i 97\% z podkarpackiego, zaś w kilku województwach (zachodniopomorskie, dolnośląskie, lubuskie) odsetek ten był niższy od $50 \%$. W efekcie jakość danych uniemożliwia m. in. ogólnopolską ocenę skutków zdrowotnych wypadków, szacowanie kosztów leczenia poszkodowanych, identyfikację zagrożeń i planowanie działań profilaktycznych.

Hospitalizacje z przyczyn niedokładnie rozpoznanych (według ICD-10 - objawów, cech chorobowych oraz nieprawidłowych wyników badań klinicznych i laboratoryjnych, gdzie indziej niesklasyfikowanych, kodowanych jako R00-R99) to zagadnienie z pogranicza kwestii opieki medycznej i jakości danych. Mimo że zarówno w Polsce, jak i na świecie zaleca się ograniczanie takich rozpoznań, jako zasadniczej przyczyny hospitalizacji $(1,2)$, w naszym kraju stanowią one prawie 5\% ogółu (w przypadku dzieci i młodzieży odsetki są znacznie wyższe - w 2017 roku taką diagnozę otrzymało 8,9\% hospitalizowanych w wieku 5-14 lat i 10,3\% w wieku 14-19 lat). Najczęściej (w ponad $30 \%$ ) są to bóle w okolicy brzucha i miednicy (R10), a w dalszej kolejności bóle w gardle lub klatce piersiowej (R07) oraz omdlenie lub zapaść (R55). Ponad $32 \%$ pacjentów wypisano w dniu przyjęcia, ale w $23 \%$ przypadków pobyt trwał 5 dni lub więcej (mediana długości pobytu wynosiła 3 dni). Zwraca uwagę, że dla $32 \%$ pacjentów rozpoznanie to kończy proces diagnostyczny/terapeutyczny.

Od 2014 roku odsetek hospitalizacji z tego powodu powoli, ale systematycznie się zmniejsza (Ryc. 1C), zwraca jednak uwagę jego znaczne zróżnicowanie regionalne (w 2017 roku 2,9\% w województwie lubuskim do niemal 6,7\% w małopolskim). Obserwowane różnice mogą wynikać z nieco odmiennej polityki przyjmowania do szpitala w poszczególnych województwach, dostępnych możliwości diagnostycznych, ale również z jakości sprawozdawczości w kwestii określania przyczyn hospitalizacji. Zagadnienie to zasługuje na odrębne, pogłębione badanie. 
chest (R07), and also syncope and collapse (R55). More than $32 \%$ patients were discharged on the day of admission, but in $23 \%$ cases the stay lasted for 5 or more days (median of the length of stay amounted to 3 days). Attention is attracted by the fact that for $32 \%$ patients this diagnosis is the final stage of the diagnostic/therapeutic process.

Since the year 2014, the percentage of hospitalisations due to that case has been decreasing slowly, but steadily (Fig. 1.C), however, its significant regional differentiation is observed (in the year 2017, from 2.9\% in Lubuskie to nearly $6.7 \%$ in Małopolskie voivodship). This effect may result from a slightly different policy of admission to hospital in particular regions, available possibilities of diagnosing, but, as well as from the quality of reporting in the aspect of determining the causes of hospitalisation. This issues deserves further and more in-depth investigation.

The better quality of data about hospitalisations would render it possible to conduct, by all the involved parties, more precise analyses, including also such as are relevant to meeting the obligations towards international organisations (WHO and OECD). Improvement in this field depends, to a significant degree, upon convincing the employees of hospitals that it matters to fill in and hand over appropriate documentation carefully and reliably, instead of perceiving this task as an unnecessary and a bureaucratic burden. This is the purpose of training, and also discussing the issue in the course of medical conferences. There is also, not frequently applied, administrative procedure of requesting intervention from the Ministry of Health or the competent provincial office.

\section{RESULTS OF THE NGHMS AND THE DATA FROM THE NATIONAL HEALTH FUND (NHF)}

The NGHMS is the oldest, but by no means the only one, source of individual data on hospital morbidity in Poland, and such data are collected by the National Health Fund (NHF) as well. The comparison of the resources of both registries may shed a light on the quality of data in both their sources, even though one ought to remember about the differences between them, resulting from different objectives of their existence (in the case of the NHF, it is to settle financial claims, whereas the NGHMS is to keep the records of public statistical data). The NHF collects data relevant to insured patients (at the end of the year 2017, there were 33 million, 786 thousand of them (3), and that means approximately $88 \%$ of the population of Poland), the NGHMS - about all the hospitalised, regardless of their status of insurance or a country of permanent residence (NHF foots the bill for approximately 90\% of the hospitalisations registered by NGHMS). Taking
Lepsza jakość danych o hospitalizacjach umożliwiłaby prowadzenie przez wszystkich zainteresowanych bardziej precyzyjnych analiz, w tym służących realizacji zobowiązań wobec organizacji międzynarodowych (WHO, OECD). Poprawa w tej dziedzinie w dużym stopniu zależy od przekonania pracowników szpitali do znaczenia starannego, rzetelnego wypełniania i przekazywania stosownej dokumentacji, bez postrzegania tej pracy jako zbędnej i obciążającej biurokracji. Służą temu szkolenia oraz podnoszenie tematu podczas konferencji medycznych. Istnieje też rzadko stosowana droga administracyjna - prośba o interwencję skierowana do Ministerstwa Zdrowia lub odpowiedniego Urzędu Wojewódzkiego.

\section{WYNIKI OBChSO A DANE NARODOWEGO FUNDUSZU ZDROWIA}

OBChSO jest najstarszym, ale nie jedynym źródłem jednostkowych danych na temat chorobowości hospitalizowanej w Polsce, dane takie zbiera również Narodowy Fundusz Zdrowia (NFZ). Porównanie zasobów obu źródeł może przynieść wiele informacji na temat jakości danych, choć trzeba pamiętać o różnicach dzielących oba zbiory, wynikających z odmiennych celów, jakim one służą (w przypadku NFZ są to rozliczenia finansowe, zaś OBChSO - statystyka publiczna). NFZ gromadzi dane dotyczące pacjentów ubezpieczonych (na koniec 2017 roku ich 33 mln 786 tys. (3), czyli ok. $88 \%$ ludności Polski), OBChSO - wszystkich hospitalizowanych, bez względu na status ubezpieczenia czy kraj stałego zamieszkania (NFZ płaci za ok. 90\% hospitalizacji zgłaszanych do OBChSO). Biorąc również pod uwagę działalność nieobjętą kontraktami z NFZ można oczekiwać, że rejestry OBChSO obejmą więcej przypadków hospitalizacji. Są jednak powody by sądzić, że rejestry NFZ będą pełniejsze - interes ekonomiczny szpitala wymaga raportowania płatnikowi wszystkich wykonanych świadczeń, podczas gdy sprawozdawczość do OBChSO wynika co prawda z ustawowego obowiązku, ale niewywiązywanie się z niego, nie oznacza jak dotąd żadnych sankcji dla placówki. Dane NFZ mogą być za to obciążone błędami wynikającymi z pochodzenia z systemu refundacyjnego i specyfiki rozliczeń z płatnikiem.

Na potrzeby niniejszej pracy porównano dane OBChSO o liczbie hospitalizacji z wybranych przyczyn $\mathrm{z}$ udostępnionymi przez NFZ $w$ ramach realizowanego w latach 2013-2017 projektu „Ograniczanie społecznych nierówności w zdrowiu”, współfinansowanego ze środków Norweskiego Mechanizmu Finansowego. Oba źródła podają podobną liczbę hospitalizacji z powodu zawałów serca (I21-I22 wg ICD-10) w latach 2009-2015, różnice nie przekraczają 10\% (Ryc. 3). 
as well under consideration the activity not covered by the contracts with the NHF, it may be expected that the records of the NGHMS ought to include more cases of hospitalisation. However, there are reasons to think that the records of the NHF ought to be more complete; the economic aspect of the activity of hospital requires that all the performed services are reported to the payer, whilst reporting to the NGHMS, even though stemming from a statutory duty, failing to comply with it has not yet been punished in any manner. The data of the NHF may instead be burdened with mistakes resulting from the fact that they originate from the claims system and from the specific character of settlements with a payer.

To meet the needs of this paper, the data of the NGHMS relevant to the number of hospitalisations from selected causes were compared with those made available by the NHF within the frameworks of (implemented in the years since 2013 until 2017), project 'Tackling social inequalities in health', partly financed with the use of means provided under the Norwegian Financial Mechanism. Both of these sources state a similar number of hospitalisations caused by myocardial infraction (I21-I22 in accordance with ICD-10) in the years 2009-2015, the biggest difference (9.2\% surplus in NGHMS data) was observed in 2014, as shown in Figure 3.
Podobną zgodność uzyskano za lata 2013 i 2014 dla hospitalizacji z powodu astmy (J45-46) i chorób wątroby (K70, K73-K74), traktowanych jako rozpoznanie zasadnicze. W tych samych latach do OBChSO zgłoszono dużo więcej (o 44\% w 2013 roku i o 59\% w 2014) hospitalizacji z powodu niewydolności nerek (N17-N19) jako choroby zasadniczej, jednak po zsumowaniu dla każdego ze źródeł przypadków chorób zasadniczych i współwystępujących, nadwyżki te redukują się do odpowiednio 3\% i 10\%. Analizowane źródła nie są zgodne co do rozpowszechnienia choroby nadciśnieniowej (I10-I15). W roku 2013 do OBChSO zgłoszono zaledwie $71 \%$, a w 2014 roku - 68\% liczby przypadków hospitalizacji raportowanych do NFZ z takim rozpoznaniem zasadniczym, po uwzględnieniu chorób współwystępujących - 78\% (w 2013 i 2014 roku).

Porównanie rejestrów NFZ i OBChSO zarówno pod względem zawartości, jak i jakości danych, wymaga bardziej szczegółowych badań. Warto jednak podkreślić, że NFZ gromadzi dane poza statystyką publiczną i nie jest zobowiązany do ich udostępniania wszystkim zainteresowanym instytucjom.

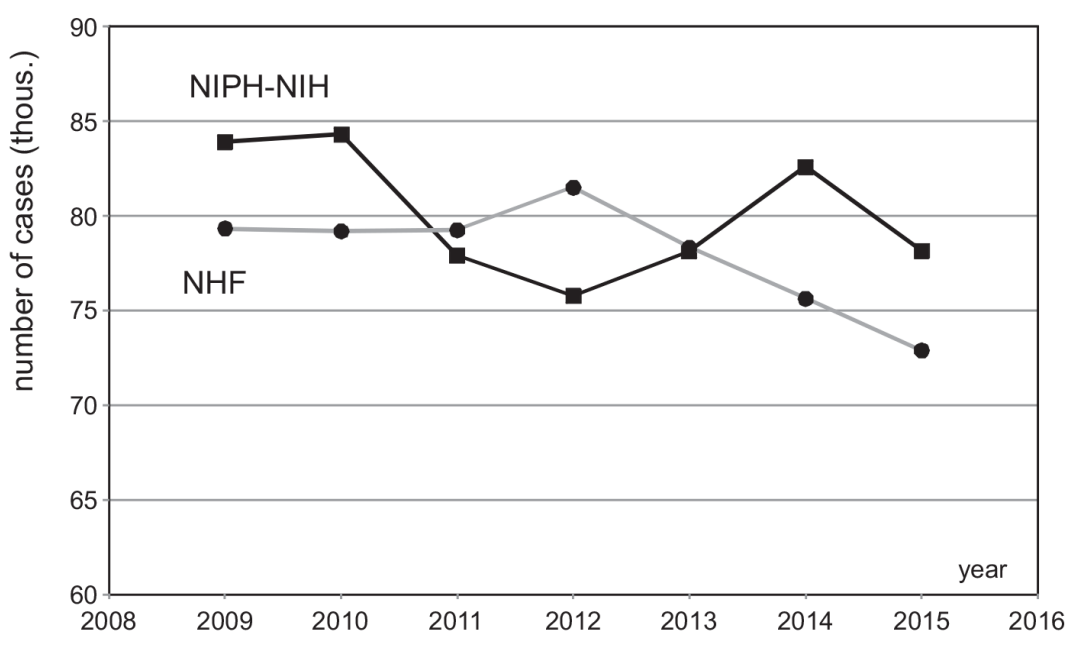

Fig. 3. Number of hospitalisations due to myocardial infraction (I21-I22) in 2009-2015 by NGHMS and NHF. Ryc. 3. Liczba hospitalizacji z powodu zawału serca (I21-I22) w latach 2009-2015 według danych OBChSO i NFZ.

A similar compatibility was obtained for the years 2013 and 2014 for hospitalisations due to asthma (J4546) and the diseases of the liver (K70, K73-K74) treated as the principal diagnosis. In these same years, the NGHMS was notified of much more hospitalisations caused by kidney failure (N17-N19) as a main disease (44\% more in the year 2013, and 59\% more in the year 2014), however, after adding comorbidity in data from both sources, these surpluses are reduced,

\section{WYKORZYSTANIE WYNIKÓW}

Mimo powyższych ograniczeń, OBChSO jest podstawowym źródłem danych dotyczących chorobowości hospitalizowanej w Polsce. Jego wyniki umożliwiają m. in. wyznaczenie częstości hospitalizacji z poszczególnych przyczyn, z uwzględnieniem lokalizacji szpitala oraz płci, wieku i miejsca zamieszkania pacjentów, analizę długości hospitalizacji, śmiertelności szpitalnej, try- 
respectively, to $3 \%$ and $10 \%$. The analysed sources do not match in terms of frequency of hospitalisation due to hypertension (I10-I15). In the year 2013, the NGHMS was notified of merely $71 \%$, and in the year 2014 of $68 \%$ of the cases reported to the NHF with the same principal diagnosis, and, after taking under consideration comorbidity, this number amounted to $78 \%$ (in the years 2013 and 2014).

Comparison between the registers of the NHF and the NGHMS, both in terms of their contents, and the quality of data, requires more detailed investigations. However, it is worth emphasising that the NHF collects data not included into the scope of public statistics, and is not obliged to make them available to all the interested institutions.

\section{ANALYSES BASED ON THE RESULTS OF NGHMS}

In spite of the above-mentioned restriction, the NGHMS is the basic source of data relevant to hospital morbidity in Poland. The results render it possible, among others, to determine the frequency of hospitalisations due to particular causes taking under consideration the localisation of hospital, and also the sex, age and the place of residence of patients, analysis of the duration of hospitalisation, in-hospital fatality, mode of admissions and discharges. The data of NGHMS were used for scientific purposes as soon as in the 1970s (4-6), whereas in the 1980s they were used, among others, in major studies comparing the various aspects of hospitalisation in Poland and in USA $(7,8)$. The papers being written are directly relevant to hospital treatment (for instance, the frequency of the occurrence of in-hospital cardiac arrest (9), hospitalisation caused by obesity (10) or asthma (11)), but, as well, the seasonality of health phenomena (12), their spatial differences (13), the effectiveness of vaccinations $(14,15)$, the prevalence of rare diseases (16-19) - in that case, the NGHMS replaced non-existent registries of diseases. Data acquired from the Study are also annually published by the Statistics Poland in the reports entitled 'Health and health care in ...' (20). Hospital morbidity is the subject-matter of one of the chapters of reports published periodically by the NIPH$\mathrm{NIH}$, entitled 'Health status of the Polish population' (21); this chapter monitors trends in this field.

Subject-related analyses are ordered as well by the Ministry of Health (frequently as a contribution to answers to the interpellation of MPs), and also the units of territorial self-government. Because of the profile of the data collected and processed in the NGHMS, the NIPH-NIH has been incorporated into the team in charge of developing a uniform model of collecting and using data relevant to the safety of road traffic coordinated by the Office of the National Road Safety Council. bu przyjęć i wypisów. Dane OBChSO wykorzystywano do celów naukowych już w latach siedemdziesiątych (4-6), zaś w osiemdziesiątych użyto ich $\mathrm{m}$. in. w znaczących pracach porównujących różne aspekty hospitalizacji w Polsce i w USA $(7,8)$. Powstające artykuły dotyczą bezpośrednio leczenia szpitalnego (np. częstości występowania wewnątrzszpitalnego nagłego zatrzymania krążenia (9), hospitalizacji z powodu otyłości (10) czy astmy (11)), ale również sezonowości i przestrzennego zróżnicowania zjawisk zdrowotnych $(12,13)$, skuteczności szczepień $(14,15)$, rozpowszechnienia chorób rzadkich (16-19) - w tym wypadku OBChSO zastępuje nieistniejące rejestry chorób. Dane z badania trafiają również do wydawanych corocznie przez GUS raportów pt. „Zdrowie i ochrona zdrowia w ... roku” (20). Chorobowości hospitalizowanej poświęcony jest, monitorujący trendy $\mathrm{w}$ tej dziedzinie, jeden $\mathrm{z}$ rozdziałów publikowanego cyklicznie przez NIZP-PZH raportu „Sytuacja zdrowotna ludności Polski” (21).

Analizy tematyczne zamawia również Ministerstwo Zdrowia (często jako wkład do odpowiedzi na interpelacje poselskie), a także jednostki samorządu terytorialnego. Ze względu na charakter zbieranych i przetwarzanych w Badaniu danych, NIZP-PZH został włączony w skład Zespołu do spraw wypracowania modelu jednolitego systemu gromadzenia i wykorzystywania danych, dotyczących bezpieczeństwa ruchu drogowego, koordynowanego przez Sekretariat Krajowej Rady Bezpieczeństwa Ruchu Drogowego.

Zestawienia danych oraz wyliczane na ich podstawie wskaźniki dotyczące opieki zdrowotnej są również przekazywane do organizacji międzynarodowych - Eurostatu, OECD, WHO (baza danych Health for All) w ramach realizacji zobowiązań naszego kraju.

Zgodnie z wymaganiami Ustawy o statystyce publicznej (Dz. U. 2018 poz. 997) rutynowe wyniki Badania są dostępne za pośrednictwem strony internetowej NIZP-PZH (http://www.pzh.gov.pl/ w zakładce Serwisy tematyczne / Chorobowość szpitalna lub bezpośrednio pod adresem: http://www.statystyka1.medstat.waw.pl / wyniki/wyniki.htm). Można tam znaleźć liczby bezwzględne hospitalizacji, współczynniki rzeczywiste na 10 tys. ludności oraz średnie dhugości pobytu w szpitalu z poszczególnych przyczyn, również w podziale według wieku (wyróżniono kategorie: poniżej 1 roku życia, 1-4 lata, 5-14, 15-19, 20-34, 35-44, 45-54, 55-64, 65 lat i więcej), płci i miejsca zamieszkania pacjentów (w układzie miasto/wieś) z lat 2003-2017.

Pełnym zbiorem danych dysponuje Zakład Monitorowania i Analiz Stanu Zdrowia Ludności NIZP-PZH. Dostępne są np. informacje o dziennej liczbie hospitalizacji w poszczególnych miastach. Miejsce zamieszkania pacjentów oraz lokalizacja szpitali mogą być analizowane na poziomie powiatów lub województw. Z danych tych korzystają instytuty naukowe sektora zdrowia 
The collations of data, and also, calculated upon their basis, indicators relevant to medical care, are as well forwarded to international organisations - the Eurostat, OECD, WHO (Health for All Database) within the frameworks of meeting the obligations accepted by our country.

In accordance with the requirements of the Public Statistics Act (Journal of Laws 2018, item 997), the results of the NGHMS are available on the web page of the NIPH$\mathrm{NIH}$ (http://www.pzh.gov.pl/ in the following bookmark: Subject-related services / hospital morbidity), or directly at the following address: http://www.statystyka1.medstat. waw.pl/wyniki/wyniki.htm. It is possible to find there the total numbers of hospitalisations, crude rates per 10,000 population, and also the average length of the hospital stay due to particular diseases according to age (with the following separate categories: under 1 year of life, 1-4 years, 5-14, 15-19, 20-34, 35-44, 45-54, 55-64, 65 years and more), sex and the place of residence of patients (by means of indicating urban or rural area) in the years since 2003 until 2017.

A complete collection of data is at the disposal of the Department of Population Health Monitoring and Analysis. Information about, for instance, a daily number of hospitalisations in particular cities is available there. The places of residence of patients, and also the localisation of hospitals, may be analysed at the level of voivodships or powiats. These data are used by scientific institutes of the health sector (hospitalisations due to cardiovascular diseases have been analysed by the Cardinal Wyszynski Institute of Cardiology, while hospitalisations due to neurological diseases by the Institute of Psychiatry and Neurology), and also the authors of scientific dissertations (Ph.D., M.A. and B.A.), papers and grant applications, sometimes commercial companies, including those in the insurance industry. For the time being (February 2019), the data for the year 2017 and the previous ones are available, whereas the collection for the year 2018 is being processed.

\section{RECAPITULATION}

The Nationwide General Hospital Morbidity Study is an important source of health data, which are used in numerous significant elaborations and papers to meet the needs of domestic and international recipients.

The collected information might be used even more frequently should knowledge about the available resources of data and opportunity of using them reach a broader group of those potentially interested.

It should be emphasised that the NGHMS collects the hospitalisation data from both public and private hospitals, regardless of the insurance status of patients.

The Study is the only Polish source of certain information-concerning the external causes of hospitalised injuries and poisonings, as well the chain of events that led (np. Instytut Kardiologii w zakresie chorób układu krążenia, Instytut Psychiatrii i Neurologii - chorób neurologicznych) oraz autorzy prac naukowych (doktorskich, magisterskich, licencjackich), artykułów i wniosków grantowych, czasem firmy komercyjne, w tym ubezpieczeniowe. W chwili obecnej (luty 2019) dostępne są dane za rok 2017 i wcześniejsze, zbiór z 2018 r. jest opracowywany.

\section{PODSUMOWANIE}

Ogólnopolskie Badanie Chorobowości Szpitalnej Ogólnej jest ważnym źródłem danych epidemiologicznych, które są wykorzystywane w wielu istotnych opracowaniach i zestawieniach na użytek krajowy i międzynarodowy.

Zgromadzone informacje mogłyby być używane jeszcze częściej, gdyby wiedza o dostępnych zasobach danych i możliwości ich wykorzystania docierała do szerszej grupy zainteresowanych.

Dane pochodzą zarówno ze szpitali państwowych, jak i prywatnych, dotyczą również pacjentów nieubezpieczonych.

Badanie jest jedynym w kraju źródłem informacji o zewnętrznych przyczynach hospitalizowanych urazów i zatruć oraz w przypadku zmarłych pacjentów o łańcuchu przyczyn prowadzących do zgonu (publikowane statystyki zgonów GUS zawierają jedynie przyczynę wyjściową).

Zbierane dane dokumentują przypadki wypisów ze szpitali, nie zawierają natomiast identyfikatorów pozwalających np. śledzić kolejne pobyty w szpitalu konkretnego pacjenta lub jego losy po opuszczeniu placówki.

Jakość niektórych danych, zwłaszcza dotyczących zastosowanych procedur medycznych oraz zewnętrznych przyczyn urazów i zatruć, nie jest zadowalająca.

Udziały niekompletnych rekordów wykazują duże zróżnicowanie regionalne, a bardzo dobre wyniki niektórych województw (np. śląskie nie nadsyła danych bez informacji o procedurach lub przyczynach zewnętrznych, w podkarpackim odsetki takich braków wynoszą odpowiednio 3\% i 2\%) świadczą, że możliwe jest zapewnienie właściwej jakości w tej dziedzinie.

Edukacja pracowników szpitali i Urzędów Wojewódzkich w kwestii znaczenia rzetelnej sprawozdawczości i jej wpływu na możliwość wykorzystania zbieranych danych jest zadaniem dla NIZP-PZH, ale także Ministerstwa Zdrowia.

Niniejszy artykuł rozwija wybrane zagadnienia poruszone w nieopublikowanym referacie pt. „Problemy z wykorzystaniem Badania Chorobowości Szpitalnej Ogólnej do oceny jakości w opiece zdrowotnej" wygłoszonym na XXI Konferencji „Jakość w Opiece Zdrowotnej” (Kraków, 29-30 maja 2017 r.). 
to the death (in the case of deceased patients, discharge record includes immediate, intermediate and underlying causes of death).

The collected data document the cases of discharges from hospitals, whereas they do not include any personal identifiers that would make it possible, for instance, to merge information about succeeding hospitalisations of a particular patient or follow this patient's further medical events after leaving a hospital.

The quality of some of the data, in particular, relevant to applied medical procedures, and also the external causes of injuries and poisonings, is not satisfactory.

Shares of incomplete records manifest a lot of differences between regions, and very good results for some of the voivodships (for instance, the Sląskie did not submit data without information about procedures or external causes) prove that it is possible to provide appropriate quality in this field.

Training of the employees of hospitals responsible for discharge data reporting to assure the maximum quality data is a task for the NIPH-NIH, but also for the Ministry of Health.

This paper studies more broadly selected issues raised in a non-published presentation entitled 'Problems of Using the Nationwide General Hospital Morbidity Study for Quality Assessment in Health Care' delivered at the $21^{\text {st }}$ Conference 'Quality in Health Care' (Cracow, 29-30 $0^{\text {th }}$ May, 2017).

\section{REFERENCES}

1. Kozierkiewicz A. Jednorodne grupy pacjentów. Przewodnik po systemie. Wyd. 1. Warszawa: NFZ; 2009:120.

2. Wilson R What are we counting with hospital episode statistics (HES). In: Davies HTO, Tavakoli M, Malek M et al., ed. Managing Quality: Strategic Issues in Health Care Management. Ed 2. New York: Routledge; 2018.

3. Narodowy Fundusz Zdrowia, Sprawozdanie z działalności Narodowego Funduszu Zdrowia za rok 2017, Warszawa, 2018: 70-1.

4. Sawicki F, Wojtyniak B, Chańska M. Chorobowość w Polsce w latach 1961-1972 wg płci i wieku. Zdr Publ 1976;87(7):501-12.

5. Wojtyniak B, Kobryń K, Ratyński A, i in. Długość okresu pobytu w szpitalach wg rozpoznania i niektórych cech demograficznych hospitalizowanych osób, Zdr Publ 1977;88(11):687-93.

6. Krzyżanowski M, Wojtyniak B. Związek częstości hospitalizacji z czynnikami pozazdrowotnymi i prognoza częstości hospitalizacji w Polsce. Zdr Publ 1979;90(6):337-44.

7. Bacon WE, Wojtyniak B, Krzyżanowski M. Hospital use by the elderly in Poland and the United States. Am J Publ Health 1984;76:1220-6.

8. National Center for Health Statistics, Kozak JL, Bacon WE, M. Krzyżanowski, et al. Hospital use in Poland and the United States. Vital and Health Statistics. Series 5. No 2. DHHS Pub. No. (PHS) 88-1478. Washington U.S.: Government Printing Office; 1988.
9. Adamski J, Nowakowski P, Goryński P,et al. Ocena częstości występowania wewnątrzszpitalnego nagłego zatrzymania krążenia w Polsce. Anaesthesiol Intensive Ther 2016;48(5):288-93.

10. Gajewska M, Goryński P, Wysocki MJ. Hospitalisation of people with obesity in Poland in years 1985-2007. Scand J Public Health 2011;39(5):540-6.

11. Jędrychowski W, Wojtyniak B, Szafraniec K, et al. Trendy chorobowości szpitalnej $\mathrm{z}$ powodu astmy u dzieci i młodzieży w Polsce. Przegl Epidemiol 2003;57:663-70.

12. Poznańska A, Wojtyniak B, Chwojnicki K, et al. Cerebrovascular diseases in Poland -inconsistent seasonal patterns of hospitalisation and mortality. Eur J Public Health 2018;28(2):376-81.

13. Wojtyniak B, Krzyżanowski M. Terytorialne zróznicowanie chorobowości szpitalnej i umieralności w Polsce. Przegl Lek 1986; 43:316-9.

14. Gajewska M, Lewtak K, Scheres J et al. Trends in Hospitalization of Children with Bacterial Pneumonia in Poland. Cent Eur J Public Health 2016;24(3):188-92.

15. Patrzałek M, Kotowska M, Goryński P, et al. Indirect effects of a 7 year PCV7/PCV13 mass vaccination program in children on the incidence of pneumonia among adults: a comparative study based on two Polish cities. Curr Med Res Opin 2016;32(3):397-403.

16. Kanecki K, Nitsch-Osuch A, Tyszko PZ, et al. Takayasu's arteritis: a rare disease in Poland. Ann Agric Environ Med 2018;25(3):469-72.

17. Kanecki K, Nitsch-Osuch A, Goryński P, et al. Wykorzystanie statystycznych danych o chorobowości w badaniach epidemiologicznych rzadkich chorób reumatycznych. Med Og Nauk Zdr 2018;24(3),153-7.

18. Kanecki K, Nitsch-Osuch A, Goryński P, et al. Paget disease of bone among hospitalized patients in Poland. Ann Agric Environ Med 2018;25(1):182-5.

19. Kanecki K, Nitsch-Osuch A, Goryński P, et al. Hospital Morbidity Database for Epidemiological Studies on Churg-Strauss Syndrome. Adv Exp Med Biol 2017;980:19-25.

20. Główny Urząd Statystyczny. Zdrowie i ochrona zdrowia w 2016 r. Warszawa, 2017 http://stat.gov.pl/obszary-tematyczne/zdrowie/zdrowie/zdrowie-i-ochrona-zdrowia-w-2016-r-,1,7.html

21. Goryński P, Wojtyniak B, Seroka W, et al. Chorobowość hospitalizowana. W: Goryński P, Wojtyniak B, red. Sytuacja zdrowotna ludności Polski i jej uwarunkowania. Warszawa: NIZP-PZH; 2018: 151-80.

Received: 6.03.2019

Accepted for publication: 12.03.2019

Otrzymano: 6.03.2019r.

Zaakceptowano do publikacji: 12.03.2019 r.

\section{Address for correspondence: Adres do korespondencji:}

Anna Poznańska

Zakład Monitorowania i Analiz Stanu Zdrowia Ludności NIZP-PZH

ul. Chocimska 24, 00-791 Warszawa

e-mail: apoznanska@pzh.gov.pl 